\title{
Use of Problem-Based Digital Comics in the Era of Disruption as an Increasing Effort Critical Thinking Skills and Learning Achievement
}

Eva Nurchurifiani ${ }^{1 凶}{ }^{1}$, Hajjah Zulianti ${ }^{2}$

${ }^{12}$ STKIP PGRI Bandar Lampung, Lampung, Indonesia

$\bowtie$ email: churifiani@gmail.com ${ }^{1}$

\section{Received:}

July 2021

Revised:

August 2021

Accepted:

August 2021

Published:

August 2021

\begin{abstract}
Learning in the era of disruption is directed at using technology optimally, and learning is directed to have critical thinking skills. Directed learning has critical thinking skills that make it difficult for students to understand the material, which causes student learning achievement to be not optimal. The teaching carried out has not been carried out innovatively due to the teacher's limitations, technological capabilities, and media. So far, learning has only conventionally. This makes students' interest in learning less and less because it is difficult to understand the material. This study aimed to determine the use of problem-based digital comics on learning achievement and critical thinking skills. The method used is a literature review. The study results show that problem-based digital comics in the era of disruption can develop critical thinking skills and improve learning achievement.
\end{abstract}

Keywords: Digital Comics, Problem Based Learning, Learning Achievement, Thinking Skills

\section{INTRODUCTION}

The shift in learning in the era of disruption requires learning to use technology optimally. This has caught the attention of many countries and has become a discourse that has attracted the attention of some groups, including educators. The era of disruption is characterized as a scholarly society that requires graduates who can compete globally. Education is needed to compete in the era of disruption. The education system must be adapted to the demands of the disruption era. In the era of disruption, there are several skills that students must have, including critical thinking skills, so that they are expected to produce graduates who have critical thinking skills as a provision for life in the future (Maryuningsih, Hidayat, Riandi \& Rustaman, 2019 \& Kemdikbud, 2016).

In line with the importance of students' critical thinking skills for future provisions, critical thinking skills must also be developed and directed in learning to have good thinking skills. Students can develop critical thinking skills as an integral part of higher education programs to meet companies or business entities (Wilkin, 2017). This 
is because students can use critical thinking skills in analyzing, evaluating, and helping to make correct and ethical decisions (Wilkin, 2017; Cheng \& Flasher, 2018). Critical thinking skills can be realized by making students motivated and involved in learning (Shah, 2017). Pleasure in learning makes it easy for students to understand the material and can achieve high learning achievement.

The attainment of education in Indonesia is still lacking and has even decreased. Several international survey results support this, one of which is the Program for International Student Assessment (henceforth PISA). The PISA survey shows Indonesia has decreased its ranking from 2015 to 2018 in all tested fields; reading scores ranked 65 to rank 72 , math scores ranked 66 to rank 72, and science scores ranked 64 to rank 70 .

This problem is supported by several factors, such as learning that has not been carried out innovatively due to the teacher's limited time, technological, and media capabilities. So far, learning has only been carried out conventionally. This makes students less interested in learning because it is difficult to understand how learning achievement is low. Conventional learning can also lead to low critical thinking skills of students (Saputra \& Salim, 2020; Fatahullah, 2016)

Based on these problems, teachers need to improve the quality of learning to have high learning achievement and critical thinking skills. Quality learning is carried out using innovative learning strategies, namely learning models and media that utilize technology. This is an effort to overcome the limitations of learning innovation by teachers and student learning difficulties in understanding the material. So teachers need to develop a media and learning model. The development of digital learning media in the form of problem-based comics is the right effort.

Several relevant studies have tested the effectiveness of PBL-based comic media and have proven feasible and effective in increasing learning achievement (Fatimah \& Widiyatmoko, 2014; Lubis, 2016; Khorunnisa, 2017). However, previous research that combined digital comic media with the PBL learning model generally focused on improving student learning achievement without analyzing the extent of students' critical thinking skills. Even though the research was carried out separately (comic media or PBL learning model without media), it has improved skills, critical thinking, and learning achievement.

This study aimed to determine the use of problem-based digital comics on learning achievement and critical thinking skills. The benefit of writing this study is that it is hoped to provide a reference for educators to carry out innovative learning. So, the students are motivated to learn, make it easier to understand the material, be a medium for developing critical thinking skills, and produce outstanding and skilled graduates in the era of disruption. 


\section{METHOD}

The method used is a literature review by conducting a study of relevant theories and research following the discussion that becomes the problem to obtain a solution from the analysis conducted. The appropriate research or articles used by researchers apply comic media, PBL learning models and are not limited to certain learning and students of certain ages. The articles used are also articles that report empirical data, analyze data and interpret the results. Keywords that are used to find relevant theories and articles are 1) comics, 2) PBL, 3) learning achievement, 4) critical thinking skills, 5) learning media, 6) learning in an era of disruption.

The analysis was carried out through several steps; categorizing the educational context and how the comic and PBL models were applied in this context. Furthermore, analyzing the research results of each article, whether the research found a significant difference in the variables they measured. The final step, synthesizing the results of the three steps above, is analyzed to find information and conclusions to answer the questions from this study.

\section{FINDINGS AND DISCUSSION}

Learning must be carried out innovatively to attract students' attention so that learning is carried out well and achieve high learning achievement. However, when students are not interested in learning from the start, it will be increasingly difficult to achieve high learning achievement. Therefore, innovative teaching and learning activities can be implemented using appropriate learning media and learning models.

The importance of using media can also be seen from the main function of the media itself, which can be used as a tool to convey information that can help students understand the material, creating learning motivation that makes learning effective (Sumiharsono \& Hasanah, 2017; Munadi, 2013; Kustandi \& Sutjipto, 2013). Apart from using learning media, the learning model also has an important role in helping students succeed and contributes the most significant to student learning outcomes (Mahmud, Buaja, \& Noh: 2018). Based on this opinion, theoretically, problem-based digital comics in learning can increase motivation and learning outcomes.

PBL-based digital comics are comics whose story content contains messages or information about a learning material, The storyline is combined with the PBL learning model syntax - performed with the stages of the PBL learning model. The choice of comic media is based on the characteristics of the comic itself, which packs the message into a story accompanied by interesting pictures and words. The development of students' analytical skills and critical thinking skills can be directed through the PBL learning model, which presents contextual problems that require students to carry out analysis in solving problems.

Combining digital comic media with the PBL learning model will be very suitable if used in learning in the era of disruption because PBL contains problems taken from 
everyday life. For example, stories in comics are presented with light language dialogue according to daily conversation. This can make it easier for students to understand the material that makes learning achievement increase.

Comics are stories that contain messages or information that the writer equates to the reader. The writer's message to the reader is contained in the story presented in the comic with interesting illustrations or pictures. Several characters play the storyline. Combining images and text coherently describes the characters' expressions and attract readers and feel entertained (Widyawati \& Prodjosantoso, 2015). Several relevant previous studies have proven the effectiveness of problem-based comic media that increase motivation and learning achievement. If the learning material is presented in comic form, it can attract students' attention, making it easier to receive the material.

Several research results support this, including the development of Andro-web comics suitable for learning, which can be used as an alternative for teachers to attract student attention and help students learn easily and practically because it provides improved illustrations in simple language (Lesmono, Bachtiar, Maryani \& Muzdalifah, 2018; Widyawati \& Prodjosantoso, 2015). The story in the comic is presented with a combination of images and text. This makes comic media have a big influence in accelerating understanding of the material because of the visuals and texts that can transfer information quickly (Maharsi, 2011).

Critical thinking skills that require reasoning and analytical skills in solving problems can be developed using the PBL learning model. The same conclusion is stated by Wahyu (2018), that problem-solving activity in PBL can accelerate understanding and increase students' higher-order thinking skills (Wahyu, 2018). The success of PBL depends on the ability to present real problems that can develop problem-solving skills to become independent. The hope of using the PBL model is that students can directly investigate and analyze real-world problems when learning in class (Aninda \& Suryadarma, 2017).

PBL is problem-oriented and team-based, with students forming small teams, and learning begins with problem identification and formulation, using real-life contexts and unstructured situations. Usually, problematic real-life situations are analyzed and understood by students, and a solution is formulated from this problem. Students who independently seek information and solve problems provide a concrete educational experience, thereby increasing motivation and involvement in the learning process (Mahmud, Buaja, \& Noh, 2018; Guerra, 2017).

Students are more satisfied if the learning is carried out using the PBL model rather than caramel or conventional methods. Therefore, it has an impact on learning achievement. The results of the study have supported this statement, that student learning achievement is higher after using problem-based learning models before the implementation of PBL in learning (Chutrtong \& Chutrtong, 2019; Mahmud, Buaja, \& Noh, 2018; Nurtanto, Nurhaji, Widjanarko, Wijaya \& Sofyan, 2018). The teacher's 
problems can make students independently try to solve these problems using various relevant sources. Finding solutions to problem-solving makes students look for relevant information to increase students' scientific literacy.

Several studies have the same conclusion that the PBL model can develop generic skills such as teamwork and critical thinking that cannot be achieved with conventional learning models (Gholami, Moghadam, Mohammadipoor, Tarahi, Sak, Toulabi, \& Pour, 2016; Jamiat, 2018; Santos \& Silvia, 2018; Sepulveda, Cabezas, Garcia \& Salamanca, 2019). This is because the syntax in the PBL model can facilitate the development of the potential for students' critical thinking.

The effectiveness test of PBL-based comics has been conducted by Rossana (2019), who concluded that PBL-based digital comics are suitable for accounting learning. This was demonstrated through due diligence by media, language, material, and practitioner experts, with an average score of $92.78 \%$. Ayuni's (2018) research results also support this conclusion. The development of comic learning media applied to mathematics material is very good because it scores of 4 in the validity test. So it can be concluded that the development of PBL-based Digital Comic Media is necessary to improve the quality of learning, low motivation, and students critical thinking skills.

The development of PBL-based comic media has also been carried out by Fatimah \& Widiyatmoko (2015). The results of the expert's assessment of the product were considered very feasible, with an average percentage of 96.76 from media, material, and language experts. The effectiveness test results show that problem-based digital comics can develop critical thinking skills and increase learning achievement. Based on this description, it can be seen that PBL has a positive role in developing students' critical thinking skills. So that if the digital comic media is presented with a problem-based story, it will be able to develop critical thinking skills and increase learning achievement.

The development supports this carried out by Rossana (2019), that students critical thinking skill increase significantly after using digital comics in problem-based learning. This is indicated by the $\mathrm{N}$-grain score mean of 0.4 . Not only improved critical thinking skills, but student learning motivation increased by 0.7 with the high category. So it can be concluded that problem-based digital comics can be used to increase students' critical thinking skills. Students with high learning motivation and critical thinking skills can influence their learning outcomes to increase student learning achievement. The results of the research support this opinion by Fatahullah (2016), which states that student achievement is higher when the student has high critical thinking skills.

\section{CONCLUSION}

Based on the literature review described above, it can be concluded that the use of PBL-based comics is very effective in overcoming learning limitations. For example, they are student learning difficulties, low motivation, critical thinking skills, and low 
student achievement. Using PBL-based digital comic media, students will be more interested in reading material, motivated to learn because it is presented with a sequential storyline and taken from everyday life. Students will also find it easier to understand the material because they can have good reasoning skills directed through the PBL learning model to lead students to think critically and produce high learning achievement.

The combination of comic media with the PBL learning model is very suitable for the characteristics of critical thinking skills that require deep reasoning and thinking. Based on the limitations of this paper which only examines the literature, recommendations for further studies can be made to realize the development of PBLbased digital comic media. It can be tested directly into learning whose material is adapted to the characteristics of comics and problem-based learning models.

\section{REFERENCES}

Aninda, B. O. \& Suryadarma, I. G. P. 2017. Penerapan PBL dengan Suplemen Komik Digital terhadap Kemampuan Pemecahan Masalah dan Sikap Peduli Lingkungan. Jurnal Bioedukatika, 5 (2), 46-53

Chutrtong, J., Chutrtong, W. 2019. Achievement of Sanitary Learning by Problem Based Learning (PBL). International Conference on Applied Human Factors and Ergonomics. 423-429

Daryanto. 2013. Media Pembelajaran: Peranannya sangat penting dalam Mencapai Tujuan Pembelajaran. Yogyakarta: Gava Media

Fatahullah, M.M. 2016. Pengaruh Media Pembelajaran dan Kemampuan Berpikir Kritis Terhadap Hasil Belajar IPS. Jurnal Pendidikan Dasar. 7(2)

Fatimah, F., \& Widiyatmoko, A. 2014. Pengembangan Science Comic Berbasis Problem Based Learning sebagai Media Pembelajaran pada Tema Bunyi dan Pendengaran Untuk Siswa SMP. Jurnal Pendidikan IPA Indonesia .3 (2) 146-153

Guerra, A. (2017). Integration of Sustainability in Engineering Education. International Journal of Sustainability in Higher Education. 18(3), 436-454

Khorunnisa, Z. F. 2017. Pembuatan Media Komik Berbasis Problem Based Learning (PBL) Sebagai Media Pembelajaran Kimia Pada Konsep Larutan Elektrolit dan Nonelektrolit. Diploma thesis, UIN Sunan Gunung Djati Bandung

Kosasih, E. 2014. Strategi Belajar dan Pembelajaran : Implementasi Kurikulum 2013. Bandung: Yrama Widya

Krissandi, A. D. S., Widharyanto, B. \& Dewi, R. P. 2018. Pembelajaran Bahasa Indonesia untuk SD : Pendekatan dan Teknis. Bekasi : Media Maxima

Kustandi, C., \& Sutjipto, B. 2013. Media Pembelajaran Manual dan Digital. Bogor: Ghalia Indonesia 
Lesmono, A. D., Bachtiar, R. W., Maryani \& Muzdalifah, A. 2018. The Instructional Based Andro Web Comics on Work and Energy Topic for Senior High School Students. Jurnal Pendidikan IPA Indonesia. 7 (2), 147-153 